\title{
Polarographic Study of Meta-Hydroxyacetanilide and its Determination
}

\section{Swaroopa Rani N Gupta*}

Department of Chemistry, Brijlal Biyani Science College, Amravati, Maharashtra, India

\begin{abstract}
Present paper deals with polarographic study of effect of maxima suppressors and supporting electrolytes on anodic waves of meta-hydroxyacetanilide and polarographic determination of meta-hydroxyacetanilide under optimum concentration of maxima suppressors and supporting electrolytes.

The polarographic method has been developed to study qualitatively the effect of maxima suppressor (fuchsin) and supporting electrolyte (nitric acid) on oxidation wave of meta-hydroxyacetanilide. Polarograms of system were recorded between 500 to $1300 \mathrm{mV}$ by using Rotating Platinum micro Electrode as anode and Saturated Calomel Electrode as cathode on D.C. Recording Polarograph using Omniscribe recorder.

It shows a similar behavior to that observed for paracetamol. It produces anodic wave at rotating platinum electrode. The oxidation yields the 3-N-acetylaminosemiquinone and represents a reversible reaction. Polarographically a value of $900 \mathrm{mV}$ is found for decomposition potential of meta-hydroxyacetanilide. Wave analysis point to 1-electron step for each wave. Waves of meta-hydroxyacetanilide are only proportional to concentration at low concentrations.
\end{abstract}

Keywords: Fuchsin; Meta-hydroxyacetanilide; Nitric acid; Paracetamol

\section{Introduction}

Acetaminophen $(250 \mathrm{mg} / \mathrm{kg})$ administered intraperitoneally to fasted, Phenobarbital-induced mice produced hepatotoxicity. No hepatotoxicity was observed after the administration of the regioisomer 3'-hydroxyacetanilide $(600 \mathrm{mg} / \mathrm{kg})$. Similar levels of covalent binding to liver homogenates occurred in mice receiving either acetaminophen or 3'-hydroxyacetanilide at these doses [1]. The administration of 3'-hydroxyacetanilide, a regioisomer of acetaminophen, to mice failed to produce hepatotoxicity even after the administration of diethyl maleate. In contrast, hepatoxicity did occur when 3'-hydroxyacetanilide was administered to buthionine sulfoximine pretreated mice [2]. Acetaminophen (4'-hydroxyacetanilide), a widely used analgesic and antipyretic drug, is hepatotoxic in large doses, whereas the m-hydroxy isomer of acetaminophen, 3'-hydroxyacetanilide, is not hepatotoxic. Both are oxidised by mouse liver cytochromes P-450 to reactive metabolites that bind covalently to hepatic proteins [3]. Acetaminophen (APAP), a widely used analgesic and antipyretic that is considered to be relatively safe at recommended doses, is the leading cause of druginduced liver failure in the United States. 3'-Hydroxyacetanilide (AMAP), a regioisomer of APAP, is useful as a comparative tool for studying APAP-induced toxicity because it is nontoxic relative to APAP. Transforming growth factor-alpha transgenic mouse hepatocytes were treated with both isomers to investigate mitogenactivated protein kinase (MAPK) cascades in order to differentiate their toxicological outcomes [4].

Acetaminophen ( $\mathrm{N}$-acetyl-p-aminophenol, APAP) is a widely used analgesic and antipyretic that is considered to be relatively safe at recommended doses. However, overdose cases are fairly common because of the widespread availability of APAP [5]. The majority of an APAP dose is metabolized to relatively nontoxic products via conjugation reactions, such as sulfation and glucuronidation [6]. The remaining dose is predominantly metabolized in the liver by cytochrome $\mathrm{P} 4502 \mathrm{E} 1$ to the presumed reactive intermediate, $\mathrm{N}$-acetylp-benzoquinoneimine (NAPQI) $[7,8]$. At therapeutic doses, low levels of P450-generated NAPQI are cleared by glutathione and glutathione$S$-transferases [9]. However, in APAP overdose situations, higher concentrations of NAPQI deplete cellular glutathione pools leading to arylation of intracellular nucleophiles by NAPQI. Modification of these nucleophilic residues within the cell can lead to oxidative/electrophilic stress resulting in hepatocellular injury [10]. A comparative tool useful for studying APAP-induced toxicity is its regioisomer, 3'-hydroxyacetanilide (N-acetyl- $m$-aminophenol, AMAP) [11-15].

Present paper deals with polarographic study of effect of maxima suppressors and supporting electrolytes on anodic waves of meta-hydroxyacetanilide and polarographic determination of meta-hydroxyacetanilide under optimum concentration of maxima suppressors and supporting electrolytes.

\section{Methodology}

All chemicals were of A.R. grade. Polarograms of all system were recorded on D.C. Recording Polarograph using Omniscribe recorder between 200 to $1300 \mathrm{mV}$ using Rotating Platinum micro Electrode (RPE) as anode and Saturated Calomel Electrode (S.C.E.) as cathode. Detail procedure is given under each heading.

Effect of maxima suppressors and supporting electrolytes on polarographic waves of meta-hydroxyacetanilide

The maxima suppressor capacity of fuchsin on the anodic wave of meta-hydroxyacetanilide in presence of $0.1 \mathrm{M} \mathrm{HNO}_{3}$ was studied by preparing three systems containing $0.6 \mathrm{ml}$ of $5 \times 10^{-3} \mathrm{M}$ metahydrxyacetanilide, $1 \mathrm{ml} 5 \mathrm{M} \mathrm{HNO}_{3}$ solution and different amount of fuchsin, viz., $0,2.5 \times 10^{-9}, 1.25 \times 10^{-5} \mathrm{~g}$ and diluted to $50 \mathrm{ml}$ with distilled water. Polarograms of each system were recorded between 500 to 1300 $\mathrm{mV}$ by using Rotating Platinum micro Electrode (RPE) as anode and Saturated Calomel Electrode (S.C.E.) as cathode. Similar experiments were carried out using various concentrations of nitric acid.

Polarographic determination of meta - hydroxyacetanilide (calibration method)

Polarograms of system containing varying concentrations of meta-

*Corresponding author: Swaroopa Rani N. Gupta, Department of Chemistry, Brijlal Biyani Science College, Amravati, Maharashtra, India, Tel: +919665041291; E-mail: swargupta@yahoo.com

Received January 11, 2016; Accepted January 23, 2016; Published January 25 2016

Citation: Gupta SRN (2016) Polarographic Study of Meta-Hydroxyacetanilide and its Determination. Med chem 6: 058-061. doi:10.4172/2161-0444.1000325

Copyright: (c) 2016 Gupta SRN. This is an open-access article distributed under the terms of the Creative Commons Attribution License, which permits unrestricted use, distribution, and reproduction in any medium, provided the original author and source are credited. 
hydrxyacetanilide in $0.1 \mathrm{M} \mathrm{HNO}_{3}$ were recorded on D.C. Recording Polarograph using Omniscribe recorder.

\section{Observations}

Effect of maxima suppressors and supporting electrolytes on polarographic waves of meta-hydroxyacetanilide

Effect of fuchsin concentration on the oxidation wave of metahydroxyacetanilide in $0.1 \mathrm{M} \mathrm{HNO}_{3}$ is given in Figure 1. Fuchsin suppresses the wave but does not improve the shape of wave thereby anodic wave is not well defined. Decomposition potential is found to be $+950 \mathrm{mV}$. Similarly $\mathrm{HNO}_{3}$ concentration exerts pronounced effect on current-potential wave of meta-hydroxyacetanilide (Figure 2). As concentration of $\mathrm{HNO}_{3}$ varies from $0.1 \mathrm{M}$ to $3 \mathrm{M}$ initial current shifts to higher values for same applied potential, at the same time increase in wave height is observed.

\section{Polarographic determination of meta-hydroxyacetanilide (calibration method)}

Polarograms obtained for different amount of metahydroxyacetanilide in $0.1 \mathrm{M} \mathrm{HNO}_{3}$ are shown in Figure 3.

\section{Results and Discussion}

There is not much literature review on the approaches used for meta-hydroxyacetanilide detection. The advantages of the application of polarography in the analysis of metahydroxyacetanilide are speed, sensitivity, which enables trace analysis to be carried out, and to follow changes in the composition of the preparation, the small sample requirements and selectivity. It is possible to carry out a polarographic analysis even in the presence of colouring matters and comparable amounts of other ingredients.

\section{Effect of maxima suppressors and supporting electrolytes on polarographic waves of meta-hydroxyacetanilide}

The polarographic method has been used to study qualitatively the effect of maxima suppressor (fuchsin) and supporting electrolyte (nitric acid) on oxidation wave of meta-hydroxyacetanilide. It shows a similar behavior to that observed for paracetamol [16-19]. Figures 1 and 2 represents effect of various concentrations of fuchsin (in 0.1 $\mathrm{M} \mathrm{HNO}_{3}$ ) and nitric acid on the anodic wave of $6.0 \times 10^{-5} \mathrm{M}$ metahydroxyacetanilide. It was found that fuchsin suppressed the wave (Figure 1) while increasing concentrations of nitric acid was found to increase residual as well as diffusion current values at the same time making the limiting current plateau much defined (Figure 2).

\section{Polarographic determination of meta-hydroxyacetanilide (calibration method)}

The log plots of the C-V curves of meta-hydroxyacetanilide in 0.1 and 3.0 $\mathrm{M} \mathrm{HNO}_{3}$ is given in Figure 4. The polarographic method has been used to identify the products of oxidation of meta-hydroxyacetanilide. In this connection the half-wave potentials $(1025 \mathrm{mV}$ and $1090 \mathrm{mV}$ vs S.C.E.) and values of $\mathrm{n}$ are determined in $0.1 \mathrm{M}$ and $3.0 \mathrm{M}$ nitric acid (Table 1) and is found to agree with the values obtained for the oxidized product. A good agreement between experimental and theoretical value is shown by the log plots of the $\mathrm{C}-\mathrm{V}$ curves of meta-hydroxyacetanilide in 0.1 and $3.0 \mathrm{M} \mathrm{HNO}_{3}$ (Figure 4).

The experimental points of the log plots gave good straight lines with slopes of 0.0656 and $0.0770 \mathrm{~V}$, in close agreement with the theoretical values which is $0.0591 \mathrm{~V}$. Hence the value of $n$, the number of electrons taking part in the reversible reaction is found to be 0.9 and $0.8(\sim 1)$.
Thus meta-hydroxyacetanilide produces anodic wave at the rotating platinum electrode. The oxidation yields the $3-\mathrm{N}$-acetylaminosemiquinone and represents a reversible reaction. Polarographically a value of 900 $\mathrm{mV}$ is found for decomposition potential of meta-hydroxyacetanilide. Wave analysis point to a 1-electron step for each of the waves. Metahydroxyacetanilide is oxidized in the following manner:

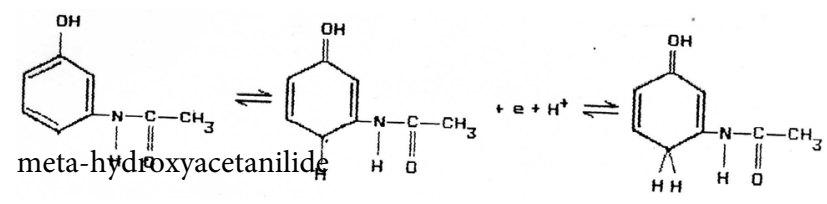

3-N-acetylaminosemiquinone

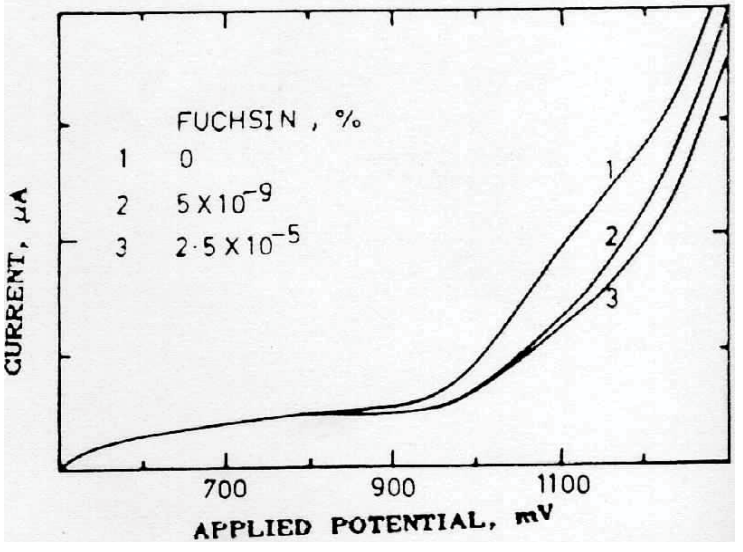

Figure 1: Effect of Fuchsin concentration on the anodic wave of $6.0 \times 10^{-5}$ $\mathrm{M}$ meta-hydroxyacetanilide in $0.1 \mathrm{M} \mathrm{HNO}_{3}$.

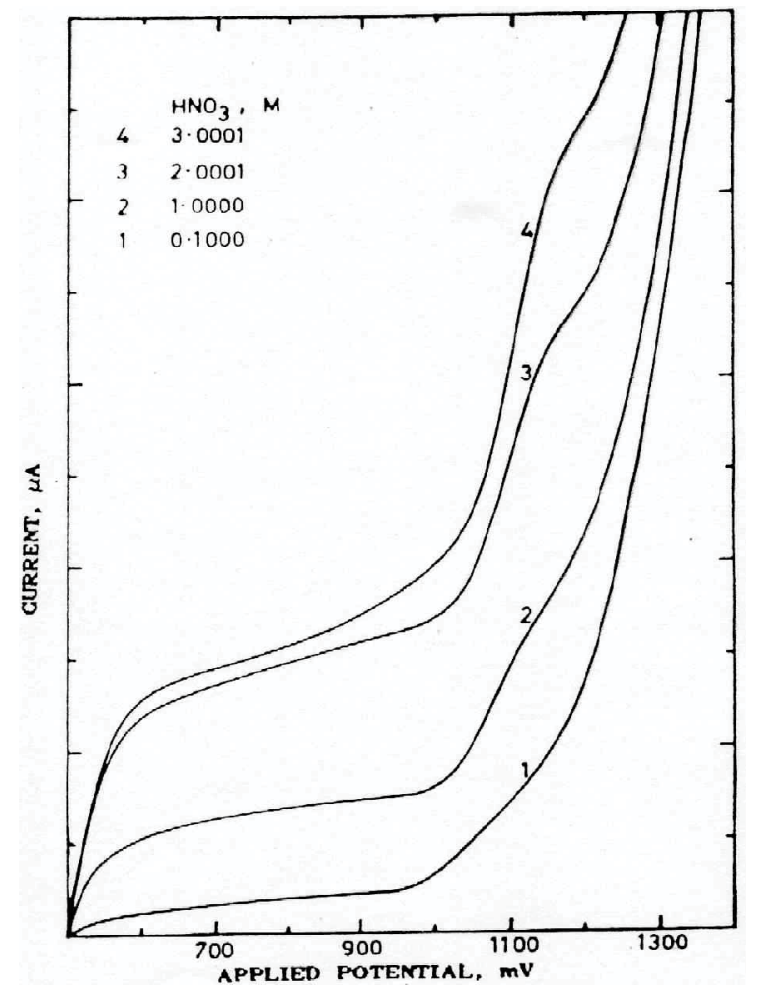

Figure 2: Effect of $\mathrm{HNO}_{3}$ concentration on the anodic wave of $6.0 \times 10^{-5} \mathrm{M}$ meta-hydroxyacetanilide. 
Citation: Gupta SRN (2016) Polarographic Study of Meta-Hydroxyacetanilide and its Determination. Med chem 6: 058-061. doi:10.4172/21610444.1000325

\begin{tabular}{|c|c|c|c|c|c|c|c|c|}
\hline \multirow{2}{*}{$\mathrm{HNO}_{3} \mathrm{M}$} & \multirow{2}{*}{ iR } & \multicolumn{2}{|l|}{ id } & \multirow{2}{*}{\begin{tabular}{|l|} 
Slope, V \\
Theoretical
\end{tabular}} & \multirow[b]{2}{*}{ Experimental } & \multicolumn{2}{|l|}{ Value of $n$} & \multirow{2}{*}{$\mathrm{E}_{1 / 2} \mathrm{mV}$} \\
\hline & & Observed & Corrected & & & Theoretical & Experimental & \\
\hline 0.1 & 1 & 1.95 & 0.85 & 0.06 & 0.07 & 1 & 0.9 & 1025 \\
\hline 3 & 4 & 8.88 & 4.98 & 0.06 & 0.08 & 1 & 0.8 & 1090 \\
\hline
\end{tabular}

Table 1: Data of log plots of the waves of meta-hydroxyacetanilide in $0.1 \mathrm{M}$ and $3.0 \mathrm{M}$ Nitric acid.

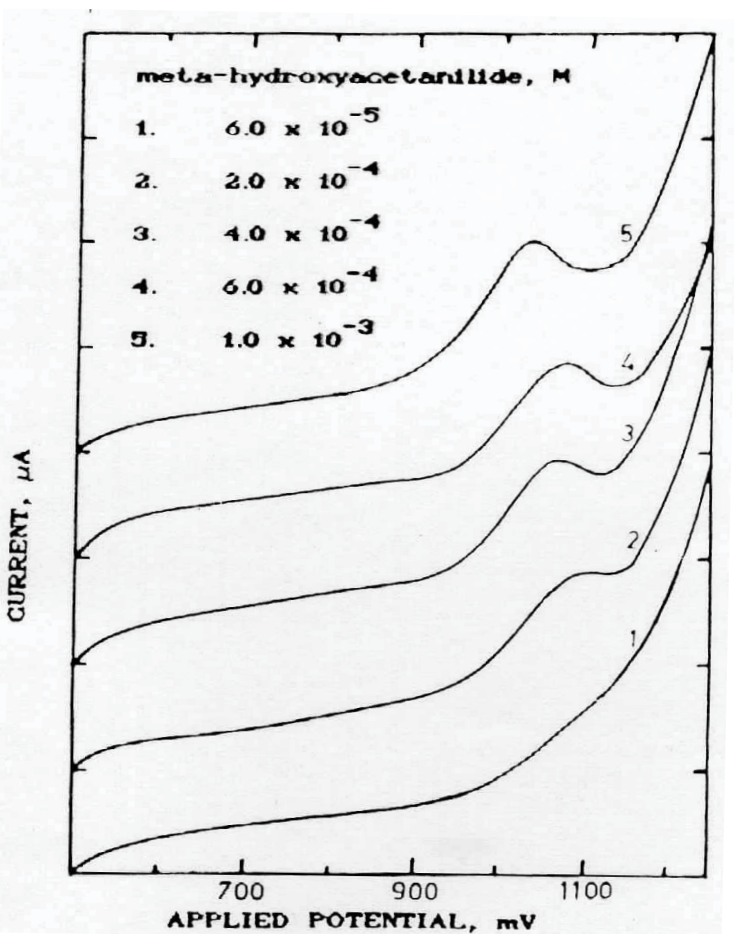

Figure 3: Calibration polarogram for meta-hydroxyacetanilide determination in $0.1 \mathrm{M} \mathrm{HNO}_{3}$.

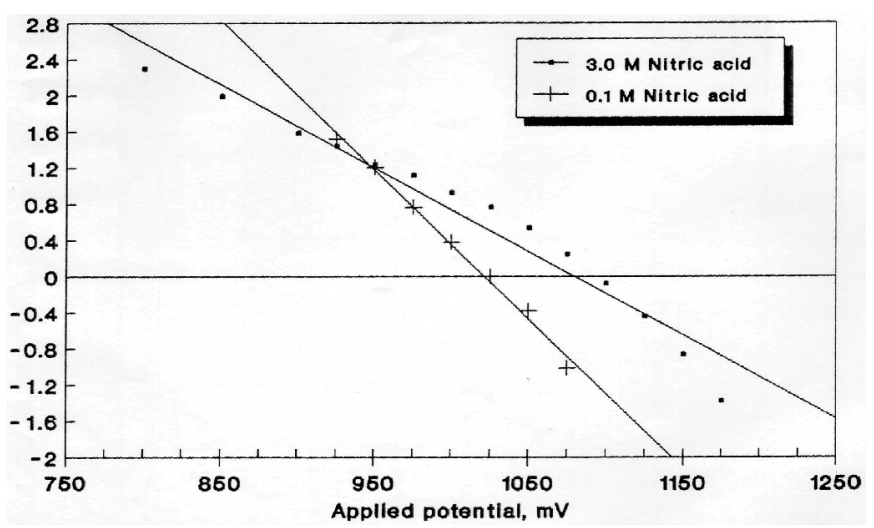

Figure 4: Test of equation of wave of $6.0 \times 10^{-5} \mathrm{M}$ Meta-Hydroxyacetanilide in Nitric acid medium; Experimental points from Figure 2.

While carrying out determination of meta-hydroxyacetanilide it is observed that waves of meta-hydroxyacetanilide are only proportional to concentration at low concentrations (below approximately $2 \times 10^{-4}$ $\mathrm{M})$. Moreover meta-hydroxyacetanilide gives no reproducible wave and the nature of it changes as concentration of meta-hydroxyacetanilide varies from $6.0 \times 10^{-5} \mathrm{M}$ to $1.0 \times 10^{-3} \mathrm{M}$ as shown in Figure 3. At 6.0 $\times 10^{-5} \mathrm{M}$ meta-hydroxyacetanilide, limiting current plateau is not well defined; at $2.0 \times 10^{-4} \mathrm{M}$ meta-hydroxyacetanilide, limiting current region become well developed; at $4.0 \times 10^{-4} \mathrm{M}$ meta-hydroxyacetanilide round streaming maxima appears which become more pronounced with further increase in its concentration.

\section{Conclusion}

The polarographic method has been used to study qualitatively the effect of maxima suppressor (fuchsin) and supporting electrolyte (nitric acid) on oxidation wave of meta-hydroxyacetanilide an analogue of paracetamol. It shows a similar behavior to that observed for paracetamol. It produces anodic wave at the rotating platinum electrode. The oxidation yields the 3-N-acetylaminosemiquinone and represents a reversible reaction. Polarographically a value of $900 \mathrm{mV}$ is found for decomposition potential of meta-hydroxyacetanilide. Wave analysis point to a 1-electron step for each of the waves. Waves of meta-hydroxyacetanilide are only proportional to concentration at low concentrations.

\section{References}

1. Tirmenstein MA, Nelson SD (1989) Subcellular Binding and Effects on Calcium Homeostasis Produced by Acetaminophen and a Nonhepatotoxic Regioisomer 3'-Hydroxyacetanilide, in Mouse Liver. The Journal of biological chemistry 264 9814-9819.

2. Tirmenstein MA, Nelson SD (1991) Hepatotoxicity after 3'-hydroxyacetanilide administration to buthionine sulfoximine pretreated mice. Chem Res Toxicol 4: 214-217.

3. Myers TG, Dietz EC, Anderson NL, Khairallah EA, Cohen SD, et al. (1995) A Comparative Study of Mouse Liver Proteins Arylated by Reactive Metabolites of Acetaminophen and Its Nonhepatotoxic Regioisomer, 3'-Hydroxyacetanilide. Chem Res Toxicol 8: 403-413.

4. Stamper BD, Bammler TK, Beyer RP, Farin FM, Nelson SD (2010) Differential Regulation of Mitogen-Activated Protein Kinase Pathways by Acetaminophen and Its Nonhepatotoxic Regioisomer 3'-Hydroxyacetanilide in TAMH Cells. Toxicological Sciences 116: 164-173.

5. Lee WM (2004) Acetaminophen and the U.S. Acute Liver Failure Study Group: lowering the risks of hepatic failure. Hepatology 40: 6-9.

6. Watari N, Iwai M, Kaneniwa N (1983) Pharmacokinetic study of the fate of acetaminophen and its conjugates in rats. J Pharmacokinet Biopharm 11: 245-272.

7. James LP, Mayeux PR, Hinson JA (2003) Acetaminophen-induced hepatotoxicity. Drug Metab Dispos 31: 1499-1506.

8. Nelson SD, Bruschi SA (2007) Mechanisms of acetaminophen-induced liver disease. In: Kaplowitz N, DeLeve LD (eds.). Drug-Induced Liver Disease. New York. Informa Healthcare. pp: 353-388.

9. Coles B, Wilson I, Wardman P, Hinson JA, Nelson SD, et al. (1988) The spontaneous and enzymatic reaction of $\mathrm{N}$-acetyl-p-benzoquinonimine with glutathione: a stopped-flow kinetic study. Arch Biochem Biophys 264: 253-260.

10. Jollow DJ, Mitchell JR, Potter WZ, Davis DC, Gillette JR, et al. (1973) Acetaminophen-induced hepatic necrosis. II. Role of covalent binding in vivo. J Pharmacol Exp Ther 187: 195-202.

11. Holme JA, Hongslo JK, Bjorge C, Nelson SD (1991) Comparative cytotoxic effects of acetaminophen ( $\mathrm{N}$-acetyl-p-aminophenol), a non-hepatotoxic regioisomer acetyl-m-aminophenol and their postulated reactive hydroquinone and quinone metabolites in monolayer cultures of mouse hepatocytes. Biochem Pharmacol 42: 1137-1142.

12. Myers TG, Dietz EC, Anderson NL, Khairallah EA, Cohen SD, et al. (1995) A comparative study of mouse liver proteins arylated by reactive metabolites of acetaminophen and its nonhepatotoxic regioisomer, 3'-hydroxyacetanilide. Chem Res Toxicol 8: 403-413.

13. Pierce RH, Franklin CC, Campbell JS, Tonge RP, Chen W, et al. (2002) Cell culture model for acetaminophen-induced hepatocyte death in vivo. Biochem Pharmacol 64: 413-424. 
Citation: Gupta SRN (2016) Polarographic Study of Meta-Hydroxyacetanilide and its Determination. Med chem 6: 058-061. doi:10.4172/21610444.1000325

14. Rashed MS, Myers TG, Nelson SD (1990) Hepatic protein arylation, glutathione depletion, and metabolite profiles of acetaminophen and a non-hepatotoxic regioisomer, 3'-hydroxyacetanilide, in the mouse. Drug Metab Dispos 18: 765-770.

15. Roberts SA, Price VF, Jollow DJ (1990) Acetaminophen structuretoxicity studies: in vivo covalent binding of a nonhepatotoxic analog 3-hydroxyacetanilide. Toxicol Appl Pharmacol 105: 195-208.

16. Gupta SN (2014) Effect of Supporting Electrolytes on Polarographic Anodic Waves of Paracetamol. International Proceedings of Chemical, Biology \& Environmental Engineering 78: 61-72.
17. Gupta SN (2014) Effect of Maxima Suppressors on Polarographic Anodic Waves of Paracetamol. International Proceedings of Chemical, Biology \& Environmental Engineering 78: 77-87.

18. Gupta SN (2014) Polarographic Determination of Paracetamol in Pharmaceutical Preparations using $0.008 \%$ gelatin and $0.1 \mathrm{M} \mathrm{HClO} 4$. International Proceedings of Chemical, Biology \& Environmental Engineering 78: 88-92.

19. Gupta SN (2014) Characterization of Paracetamol and Meta-Hydroxyacetanilide. International Journal of Chemical and Physical Sciences 4: 289-295. 